\title{
Increasing Entrepreneurial Interest for Children with Special Needs Through Entrepreneurship Education
}

\author{
Monry Fraick Nicky Gillian Ratumbuysang \\ Economic Education Study Program, Teaching and Education Faculty \\ Banjarmasin, Indonesia \\ monryratumbuysang@gmail.com
}

\begin{abstract}
Having a decent job and life is a dream of people with disabilities. Working is a basic need for people with disabilities. Because it is difficult to find employment, entrepreneurship is then seen as one of the future alternatives for people with special needs. The implementation of entrepreneurship education is carried out by principals, teachers, education personnel (counselors), as well as students as an educational community. Entrepreneurship education is directing children with special needs to master special skills a a provision to work that is related with their field or open their own business. The implementation of entrepreneurial learning for children with special needs includes the learning process of entrepreneurship, which is integrated in the education of life skills that emphasize practical activities after debriefing on entrepreneurship learning theory, the learning methods used include communication, direct instruction, and prompt, the results of entrepreneurial education are products that are ready to be ready and easily marketed in the form of handicrafts and culinary and services. It is recommended that entrepreneurship education conducted at Special Schools should be integrated into vocational skills education that emphasizes practice.
\end{abstract}

Keywords-entrepreneurial interest; entrepreneurship education; children with special needs.

\section{INTRODUCTION}

The arising of entrepreneur determined the increasing of economic of the state. While the number of entrepreneurs in Indonesia currently is $1.56 \%$, lower than the target of the world bank that require $4 \%$ to face the MEA. This means that Indonesia still needs 1.7 million entrepreneurs to reach the target of $2 \%$, and 5.8 million entrepreneurs to reach the target of $4 \%$ from the World Bank [1].

According to the World Bank, the country that has a good and advanced economy is at least $4 \%$ of its citizens are entrepreneurs. Indonesia has only $3.3 \%$ until now. Singapore 7 $\%$, and Malaysia $5 \%$ [2].

President Joko Widodo said he was concerned by the growth in the number of entrepreneurs in Indonesia which still low compared to other countries. Referring to the index of global entrepreneurship in 2017, Jokowi said that Indonesian entrepreneurship rank 90th out of 137 countries in the world. Not only it is ranked low in the world, even at the Asia Pacific level Indonesia's entrepreneurial ranking refers to the same data which is still 16th out of 24 countries [1]. Nowadays, entrepreneurs can be born not because of mere talent. The spirit of entrepreneurship can be developed through education which promotes theory and practice that is suitable with the ethics.

The theory and practice of entrepreneurship can be obtained through entrepreneurship education. Like other normal children, children with special needs are also entitled to education. This is in line with the principle of Education for All (education for all) which is the elaboration of the 1945 Constitution regarding education for Indonesian citizens.

This was mentioned in the 1945 Constitution article 28 paragraph (1) which says that: Everyone has the right to develop themselves in order to fulfill his basic needs, the right to have education and to benefit from science and technology, art and culture in order to improve the quality of his life for the welfare of mankind. The mandate was also confirmed in the 1945 Constitution article 31 paragraph (1) which states that: -Every citizen has the right to get education.

Children with special needs (formerly referred to as extraordinary children) are defined as children who need special education and services to develop their potential. In the education, extraordinary words are designed for those who have lack or experience a variety of disability [3]. Children with special needs are children with different special characteristics in children in general. So it can be concluded that children with special needs are children who has special characteristics that distinguish them from normal children in general and require special education according to their type of disability.

According to Ministry of National Education [4] learning for children with special needs includes entrepreneurship program. The objectives of the entrepreneurship education program are education units ranging from early childhood education to senior secondary education and non-formal education (PAUD/TK, SD/MI/SDLB, SMP/MTs/SMPLB, MA /MA/SMALB, and SMK/MAK, to PNF) Through this program it is expected that graduated students have the spirit and entrepreneurial spirit [4]. 


\section{METHOD}

This article is a literature review. In the most rigorous form of research, educators base this review mainly on research reported in journal articles [5].

\section{RESULT AND DISCUSSION}

\section{A. Entrepreneurship Interest in Children with Special Needs}

Interest is the acceptance of a relationship within inner yourself and outer yourself. The stronger or the closer the relationship is, the greater the interest would be. According to Crow \& Crow [6], said interest is encouraging a person to face or deal with people, objects, activities, experiences stimulated by the activity itself. Interest is defined as someone's tendency to be interested in a particular field of study or subject matter and feel happy to learn the material [7]. Moment's interest is a feeling of being interested in a topic that is being discussed or studied for that often used the term "attention". The word attention in "momentary interest", needs to differ from attention in "concentration", as explained above. Between interest and feeling happy about reciprocal relationships, so it is not surprising that students who feel unhappy, will be less interested, and vice versa. Based on the explanation about the meaning of interest mentioned from several sources above, it can be concluded that interest is a sense of interest in something or activity without any compulsion and feel happy to learn it. This sense of attraction is not due to coercion but high awareness because of a strong desire to achieve the goals.

Children with special needs or ABK are children who has disability either physically, mentally / intellectually, socially, and emotional disturbances (dysfunction) which permanent (for example: children with mental retardation, hearing impairment, physical impairment, blindness, autism, hyperactivity, cerebral palsy, and children with specific learning disorders) or those that are temporary (example: children who experience trauma after a disaster or disaster). With all its shortcomings, they should have the same opportunity to have life as normal children in general, namely a decent living space and equal opportunities to optimize their potential.

Having a decent job and life is a dream of people with disabilities. Working is a basic need for people with disabilities. Based on the data obtained in Rokhim \& Handoyo's research [8] working for workers with disabilities can be defined as follows: (1) self-existence, (2) effort to collect capital, (3) to adapt to the social environment, (4) producer additional family, and (5) the main source of family income. For people with disabilities, the regulation is a foundation to improve their life, had a legal basis. Opportunities to get equality, such as in education, employment / employment, the same treatment in various aspects of life and livelihood are officially guaranteed by law.

Because it is difficult to find employment, entrepreneurship as one of the future alternatives for people with special needs to get employed [9,10]. Winasti's research [10] showed people's motivation in entrepreneurship is to provide for their families, establish relationships with people, help people with physical disabilities to be more prosperous, have self-esteem, and desire to be equal to normal individuals.
Therefore, entrepreneurship for individuals with special needs requires a lot of assistance from various parties. Arnold, Seekins, \& Ravesloot [11] suggested that there are many fields that can be used as entrepreneurs for individuals with special needs.

Arnold (12) recommend steps as an entrepreneurship guidance for children with special needs, include: (1) Individuals express interest in entrepreneurship. There are individuals who are convinced of entrepreneurship and some are not. Individuals who are still hesitant need to be convinced that entrepreneurship is a choice and purpose in life. (2) Advisors and individuals discuss the advantages and disadvantages of entrepreneurship. In this step, the mentor and the individual will be discussed on the business idea. (3) Feasibility study, the two stages are, developing ideas to be more concrete by detailing the planned business, what is being produced, who are the customers, the costs and income expected from the business.

Entrepreneurs usually plan their business grandiosely so when they need to perform the idea, the special need entrepreneur becomes backward and feel unable. Counselors need to identify whether feelings are due to disability or for other reasons, and what assistance they need. (4) Assessing the individual potential for entrepreneurship, how strengths and weaknesses of individual character and personality can be strengthened and developed through training or mentoring. (5) Identify of sources for training, education, and people who can help to prepare themselves for entrepreneurship. It starts by identifying the knowledge and skills that must be required by individuals to improve their business. Services, education, or training can help individuals develop business plans or improving their skills or knowledge. (6) Individuals who successfully complete services, training, or education. They need to be evaluated whether the training or education is suitable with the needs and whether the individual is satisfied with the ability acquired. At this time, the initial business plan was re-evaluated, whether the individual was still interested in entrepreneurship. This determination needs to be continued in an increasingly concrete direction. (7) Individuals and counselors work with consultants to develop strategic plans, marketing, funding and funding sources.

Counselors and individuals evaluate all drafts of the business plan to ensure complete and comprehensive, especially if business proposals are needed to submit fees to funding institutions (banks, credit institutions, governments, etc.). To develop entrepreneurship programs in schools for students with special needs, it is necessary to have data on entrepreneurial needs for students with special needs. Therefore, this research attempts to identify entrepreneurial needs for students with special needs.

\section{B. Entrepreneurship Education in Schools of Children with Special Needs}

Entrepreneurship is an attitude, soul and ability to create something new that is very valuable and useful for him-self and others. Entrepreneurship is a mental and mental attitude that is always active or creative empowered, creative and modest and strives to increase revenue in its business activities. 
Someone who has an entrepreneurial character is always dissatisfied with what he has achieved. Entrepreneurs are people who are skilled at taking advantage of opportunities in developing their business with the aim of improving their lives. An entrepreneur is someone that creates a new business in the face of risk and uncertainty for the purpose of achieving profit and growth on those opportunities [13]. Entrepreneurs are people who have the ability to see and assess business opportunities; collect the resources needed to take appropriate action, take advantage and have the nature, character and willingness to create innovative ideas into the real world creatively in order to achieve success / increase income. In essence, an entrepreneur is a person who has the character of entrepreneurship and applies the nature of entrepreneurship in his life. In other words, entrepreneurs are people who have high creative and innovative souls in their lives.

Entrepreneurship education aims to form humans as a whole (holistic), as people who have the character, understanding and skills as entrepreneurs. Basically, entrepreneurship education can be implemented in educational activities in schools. The implementation of entrepreneurship education is carried out by principals, teachers, education personnel (counselors), as well as students as an educational community. Entrepreneurship education is applied to the curriculum by identifying types of activities in schools that can relate to entrepreneurship education and can raise awareness of in their daily lives. In this case, the entrepreneurship education program in schools can be integrated with various aspects [14].

According to Dewi, Yani and Suhardini [15], entrepreneurship education can be implemented in an integrated manner in the process of education in schools with various activities. Some models of integrating entrepreneurship education in schools can take the form of: (a) entrepreneurship education reflected in all subjects, (b) entrepreneurship education reflected in extra-curricular activities, (c) entrepreneurship education in self-development, (d) entrepreneurship education that practices theory, (e) entrepreneurship education in books and teaching materials, (f) entrepreneurship education through the establishment of school culture, and $(\mathrm{g})$ incorporating entrepreneurship education into local school content.

According to Hananta [16] stated that entrepreneurship education in children with special needs is done by directing them to mastering special skills as a provision to produce a work that is appropriate to their field or open their own business. Through this entrepreneurship education, children with special needs are able to apply themselves to participate in developing the world of entrepreneurship in Indonesia.

Entrepreneurship education is empowering the individuals' independence and integrating them education skills. These two education programs will simultaneously facilitate the characterization of entrepreneurship in children with special needs. In the first step, children with special needs need to be empowered with skills education. Empowerment of children with special needs is intended to improve human resources, strengthen the potential of students through skills and social services education by applying the principles of mutual cooperation, togetherness, self-sufficiency and participation.
In addition, it provides and increases motivation to progress from powerlessness so that it is able to live independently and can work, especially to create jobs in the community. Each student has different potential from one another by recognizing, providing skills training that is appropriate to their talents and interests, motivating and encouraging achievement.

In addition, it provides and increases motivation to live independently and employed, especially to create jobs in the community. Each student has different potential from one another by recognizing, providing skills training that is appropriate to their talents and interests, motivating and encouraging achievement.

\section{CONCLUSION}

Based on the discussion above, it can be concluded that the implementation of entrepreneurship learning for children with special needs includes: (1) the entrepreneurial learning process integrated in the education of life skills that emphasize practical activities after debriefing entrepreneurship learning theory (2) the learning methods used include communication, direct instruction, and prompt, (3) The results of entrepreneurship education are products that are ready to be ready and easily marketed in the form of handicrafts and culinary and services. It is recommended that entrepreneurship education conducted at Special Schools should be integrated into vocational skills education that emphasizes practice. Entrepreneurship learning methods are quite diverse. The choice of the method is adjusted to the student's situation and is expected to support effective learning, such as the method of learning communication, direct instruction and prompt. In the marketing of products resulting from the skills produced by children with special needs should be included in exhibitions held by the government to motivate other children with special needs.

\section{REFERENCES}

[1] Tempo.com, Kewirausahaan Indonesia ke-90 Dunia, Jokowi: Jangan Tepuk Tangan, 2018.

[2] Kompas.com. Apa Jadinya Indonesia Tanpa Wirausaha?, 2018

[3] A. Hadits, Pendidikan Anak Berkebutuhan Khusus, Bandung: Alfiabet, 2006.

[4] K. P. N. B. P. Dan, Pengembangan Pusat Kurikulum. Pedoman Pelaksanaan Pendidikan Karakter, Jakarta: Balitbang Diknas, 2010.

[5] J. W. Creswell, Educational Research, Boston: Pearson Education, Inc, 2012.

[6] H. Djaali, Psikologi Pendidikan, Jakarta: Bumi Aksara, 2008

[7] W. S. Winkel, Psikologi Pengajaran. Media Abadi, Yogyakarta: 2004.

[8] F. Rokhim and P. Handoyo, "Makna Kerja bagi Penyandang Disabilitas di Yayasan Bina Karya "Tiara Handycraft" Surabaya," Paradigma, vol. 3, no. 03, pp.1-9, 2015.

[9] I. Syamsi, "Membuka Peluang Berwirausaha untuk Pemberdayaan Anak Berkebutuhan Khusus," Jurnal Pendidikan dan Kebudayaan Dikbud, vol 16, no 1, pp.90-103, 2010.

[10] M. Winasti, "Motivasi Berwirausaha Pada Penyandang Disabilitas Fisik," Empathy Jurnal Fakultas Psikologi, vol. 1, no. 1, pp.177-187, 2012 .

[11] N. L. Arnold and T. Seekins, "Self-Employment as a Vocational Rehabilitation Closure," Journal of Disability Policy Studies, vol. 5, no. 2, pp. 65-80, Jul. 1994. 
[12] N. Arnold, T. Seekins, C. Ipsen, and K. Colling, "Self-Employment for People with Disabilities in the United States: A Recommended Process for Vocational Rehabilitation Agencies," Australian Journal of Career Development, vol. 12, no. 1, pp. 49-57, Apr. 2003

[13] N. M. Scarborough, and T. W. Zimmerer, Kewirausahaan dan Manajemen Usaha Kecil, Jakarta: Salemba Empat, 1995.

[14] M. M. Priyanti, S. Sudariyah, L. Mahmudah and M. Salimi, "Upaya Pemberdayaan Anak Berkebutuhan Khusus Melalui Pembelajaran
Kewirausahaan Di SLB Negeri Purworejo," In Prosiding Seminar Nasional Inovasi Pendidikan. August. 2016.

[15] L. Dewi, A. Yani, and A. D. Suhardini, "Model Pendidikan Karakter dan Kewirausahaan Berbasis Etnopedagogis di Sekolah Dasar Kampung Cikondang," MIMBAR, Jurnal Sosial dan Pembangunan, vol. 31, no. 2, p. 399, Dec. 2015.

[16] A. T. Hananta, "Studi Eksplorasi Pendidikan Kewirausahaan di Sekolah Dasar Unggulan Aisiyah Bantul," Jurnal Pendidikan Guru Sekolah Dasar, vol. 16, no. 4, pp.3-11, 2015. 